\title{
Effects of microencapsulated complex of organic acids and essential oils on growth performance, nutrient retention, blood profiles, fecal microflora and lean meat percentage in weaning to finishing pigs
}

\begin{tabular}{|c|c|}
\hline Journal: & Canadian Journal of Animal Science \\
\hline Manuscript ID & CJAS-2018-0006.R3 \\
\hline Manuscript Type: & Article \\
\hline Date Submitted by the Author: & 08-May-2018 \\
\hline Complete List of Authors: & $\begin{array}{l}\text { Oh, Han jin; Chungbuk National University, Animal Science } \\
\text { Kim, I.H.; Dankook University, Department of Animal Resource, and } \\
\text { Science } \\
\text { Song, M. H.; Chungnam National University, Swine Nutrition } \\
\text { Kwak, Woogi; Chungbuk National University, Animal Science } \\
\text { YUN, WON; Chungbuk National University, animal science } \\
\text { Lee, JiHwan; Chungbuk National University, Animal Science } \\
\text { Lee, ChangHee; Chungbuk National University, Animal Science; Chungbuk } \\
\text { National University } \\
\text { Oh, Seo Young; Chungbuk National University, Animal Science } \\
\text { LIU, SHUDONG; Chungbuk National University, animal science } \\
\text { An, Ji Seon; Chungbuk National University, Animal Science } \\
\text { Bum Kim, Hyeun; Dankook University, } \\
\text { Cho, Jin Ho }\end{array}$ \\
\hline Keywords: & $\begin{array}{l}\text { microencapsulation, organic acids, essential oils, growth performance, } \\
\text { nutrient digestibility }\end{array}$ \\
\hline
\end{tabular}


$\mathrm{OH}$ et al., Effects of organic acids and essential oils in weaning to finishing pigs

\section{Effects of microencapsulated complex of organic acids and essential oils on growth performance, nutrient retention, blood profiles, fecal microflora and lean meat percentage in weaning to finishing pigs.}

Han Jin $\mathrm{Oh}^{a, \#}$, In Ho Kim ${ }^{c, \#}$, Min Ho Song ${ }^{b, \#}$, Woo Gi Kwak ${ }^{a, \#}$, Won Yun ${ }^{a}$, Ji Hwan Lee ${ }^{a}$, Chang Hee Lee ${ }^{a}$, Seo Young $\mathrm{Oh}^{a}$, Shudong Liu ${ }^{a}$, Ji Seon An ${ }^{a}$, Hyeun bum Kim ${ }^{c, *}$ and Jin Ho $\mathrm{Cho}^{a, *}$

${ }^{a}$ Department of Animal Sciences, Chungbuk National University, Cheongju, Chungbuk, Republic of Korea 286-44

${ }^{b}$ Division of Animal and Dairy Science, Chungnam National University, Daejeon, Choongnam, Republic of Korea 341-34

${ }^{c}$ Department of Animal Resource, and Science, Dankook University, Cheonan, Choongnam, Republic of Korea 311-16

\# These authors contributed equally to this work.

* Correspondence to: Jin-ho Cho,

Department of Animal Science, Chungbuk National University, 1, Chungdae-ro, Seowongu, Cheongju-si, Republic of Korea.

Tel: +82-043-261-2544: Fax: +82-043-273-2240,E-mail: jinhcho@chungbuk.ac.kr

* Correspondence to: Hyeun-Bum Kim

Department of Animal Resource, and Science, Dankook University, Cheonan, Choongnam, Republic of Korea 311-16

Tel: +82-041-550-3652: Fax: +82-041-550-3604,E-mail:hbkim@dankook.ac.kr 
$\mathrm{OH}$ et al., Effects of organic acids and essential oils in weaning to finishing pigs

\begin{abstract}
A total of 90 pigs $(6.47 \pm 0.27 \mathrm{~kg}$; $21 \mathrm{~d}$ of age $)$ were used in this 22 -wk feeding trial to evaluate the effect of microencapsulated complex of organic acids and essential oils (MOE) on growth performance, nutrient retention, blood profile, fecal microflora and lean meat percentage in pigs. Pigs were randomly distributed to one of three treatment groups (6 replicate pens / treatment, 5 pigs / pen). Dietary treatments were: CON, basal diet; MOE 1, basal $+0.1 \%$ MOE, MOE2, basal diet $+0.2 \%$ MOE.

The ADG, ADFI and G/F ratio were a significantly different among treatments $(P<0.05)$. The ATTD of DM was linearly increased $(P<0.05)$ by MOE2. RBC and IgG were significantly different in pigs fed MOE $(P<0.05)$. The Lactobacillus concentration linearly increased $(P<0.05)$ in MOE2 treatments compared with other treatments. The meat color $\left(\mathrm{a}^{*}\right)$ and drip loss decreased linearly $(P<0.05)$ with increasing level of MOE. In conclusion, MOE supplementation could improve growth performance, nutrient retention, blood profile, fecal microflora and carcass trait in weaning to finishing pigs.
\end{abstract}

Key words: microencapsulation, organic acids, essential oils; growth performance; nutrient retention; pigs

\begin{abstract}
Abbreviations: OA, organic acid; EO, essential oil; MOE, microencapsulated complex of organic acids and essential oils; BW, body weight; CON, control diet; ADG, average daily gain; ADFI, average daily feed intake; G:F, feed efficiency; ATTD, apparent total tract digestibility; DM, dry matter; N, nitrogen; UV, ultraviolet; IgG, immunoglobin G; WBC, white blood cell; RBC, red blood cell; L*, lightness; a*, redness; b*, yellowness; WHC, water holding capacity; LMA, longissimus muscle area; GLM, general linear model;
\end{abstract}


$\mathrm{OH}$ et al., Effects of organic acids and essential oils in weaning to finishing pigs

\section{INTRODUCTION}

The first ban on the farm use of antibiotic growth promoters was enacted in1986 in Sweden because antibiotics in livestock feed increase numbers of antibiotic-resistant pathogens and antibiotic residue problems in animal products (Kelley et al., 1998).It is well accepted that organic acid $(\mathrm{OA})$ can reduce the $\mathrm{pH}$ in the gastrointestinal tract and moderate the microorganism balance (Canibe et al., 2005).Feeding OA to farm animals improved growth performance and nutrient retention (Wang et al., 2009). Similar to organic acid, pure botanicals, which are also referred as volatile or ethereal oils acquired from natural plant materials, can also affect animal growth performance (Simonson, 2004) and nutrient retention (Windish et al., 2008) by enhancing digestive enzyme activity and nutrient absorption (Burt, 2004).

Essential oils (EO)extracted from edible plants such as thymol and vanillin have broad spectrum of antimicrobial activity due to high content of phenolic derivatives (Falcone et al., 2005). Organic acid and EO have an antimicrobial action in common and are emerging as substitute for antibiotics (Canibe et al., 2005; Cho et al., 2006). Microencapsulation technology can be used to solve this problem because they allow for the slow release and passes along the intestine (Piva et al, 1997). Many studies have shown that microencapsulated blend (OA and EO) improved growth performance and odor reduction of pigs (Grilli et al., 2010; Cho et al., 2006) and improved broilers meat quality (Goksoy et al., 2010).

Therefore, we conducted this study to evaluate the effect of microencapsulated complex of organic acids and essential oils (MOE) supplementation on growth performance, nutrient retention, blood profiles, and fecal microflora in weaning to finishing pigs.

\section{MATERIALS AND METHODS}


$\mathrm{OH}$ et al., Effects of organic acids and essential oils in weaning to finishing pigs

The experimental protocols describing the management and care of animals were reviewed and approved by the Animal Care and Use Committee of Chungbuk National University.

\section{Animals and Facilities}

A total of 90 weaned pigs [(Yorkshire $\times$ Landrace $) \times$ Duroc] with an average body weight (BW) of $6.47 \pm 0.27 \mathrm{~kg}$ were used in a 22-wk experiment. Pigs were allotted to one of three dietary treatment in a completely randomized block design based on initial BW. There were five pigs treatment in a pen and six replicate pen per treatment. All pigs were housed in an environmentally-controlled room, which provided $0.26 \mathrm{~m}^{2}$ for each growing pig and $0.53 \mathrm{~m}^{2}$ for each finishing pig. Each pen was equipped with a one-sided, stainless steel self-feeder and a nipple drinker. Feed and water were available ad libitum. Individual pig BW and feed disappearance were recorded at the end of wk 1,3, 6, 12, 17 and 22 to determine average daily gain (ADG), average daily feed intake (ADFI), and feed efficiency (G/F) ratio.

\section{Dietary Treatments}

Dietary treatments were: Control (CON), basal diet; MOE1, basal + 0.1\% (weanling phase) \& $0.025 \%$ (growing-finishing phase) MOE; MOE2, basal diet $+0.2 \%$ (weanling phase) $\&$ $0.05 \%$ (growing-finishing phase) MOE. The diets were fed during the experiment in 3 phases: d 0 to 42,43 to 84 , and 85 to 154 . The MOE is a microencapsulated feed additive containing organic acids and pure botanicals from VetAgroSpA (Aviplus ${ }^{\circledR}$-S, 42100 Reggio Emilia, Italy), contained citric (25\%), sorbic (16.7\%) acids, thymol (1.7\%) and vanillin $(1.0 \%)$

All diets, in pelleted form, were formulated to meet or exceed the nutrient requirements (NRC, 2012) for pigs. Treatment additives were included in the diet by replacing the same 
amount of corn, and each treatment was made isolysinic and isocaloric by manipulation of soybean meal and fat source.

\section{Sampling and Measurements}

Apparent total tract digestibility (ATTD) of dry matter(DM) and nitrogen(N) was determined using chromic oxide (0.2\%) as an inert indicator (Fenton and Fenton, 1979). Pigs were fed diets mixed with chromic oxide from d 15 to 21,36 to 42,78 to 84 and 147 to 154 . Fresh fecal grab samples collected from 8 pigs per treatment (d 21, 42 and 84) were mixed and pooled, and a representative sample was stored in a freezer at $-20^{\circ} \mathrm{C}$ until analyzed. Before chemical analysis, the fecal samples were thawed and dried at $70^{\circ} \mathrm{C}$ for $72 \mathrm{~h}$, after which they were finely ground to a size that could pass through a 1-mm screen. All feed and fecal samples were, then, analyzed for DM and $\mathrm{N}$ following the procedures outlined by the AOAC (2000). Chromium was analyzed via UV absorption spectrophotometry (Shimadzu, UV-1201, Shimadzu, Kyoto, Japan) following the method described by Williams et al. (1962).

For the serum profile, 5 pigs from each treatment were randomly selected and blood samples were collected via anterior vena cava puncture at the end of wk 6,12 , and 22 . At the time of collection, blood samples were collected into both non-heparinized tubes and vacuum tubes containing $\mathrm{K}_{3}$ EDTA (Becton, Dickinson and Co., Franklin Lakes, NJ) to obtain serum and whole blood, respectively. After collection, serum samples were centrifuged $(3,000 \times \mathrm{g})$ for $15 \mathrm{mins}$ at $4^{\circ} \mathrm{C}$. The white blood cells (WBC), red blood cells (RBC), lymphocyte counts, as well as the immunogloblin G (IgG) concentration in the whole blood were determined using an automatic blood analyzer (ADVIA 120, Bayer, NY).

\section{Procedures of Microbial Shedding}


$\mathrm{OH}$ et al., Effects of organic acids and essential oils in weaning to finishing pigs

Fecal samples were collected directly via massaging the rectum of 4 pigs in each treatment and then pooled and placed on ice for transportation to the lab. One gram of the composite fecal sample from each pen was diluted with $9 \mathrm{~mL}$ of $1 \%$ peptone broth (Becton, Dickinson and Co., Franklin Lakes, NJ) and then homogenized. Viable counts of bacteria in the fecal samples were then conducted by plating serial 10 -fold dilutions (in $1 \%$ peptone solution) onto MacConkey agar plates (Difco Laboratories, Detroit, MI) and lactobacilli medium III agar plates (Medium 638, DSMZ, Braunschweig, Germany) to isolate the E. coli and lactobacillus, respectively. The lactobacilli medium III agar plates were then incubated for 48 $\mathrm{h}$ at $39^{\circ} \mathrm{C}$ under anaerobic conditions. The MacConkey agar plates were incubated for $24 \mathrm{~h}$ at $37^{\circ} \mathrm{C}$. The E. coli and lactobacillus colonies were counted immediately after removal from the incubator.

\section{Carcass traits}

Twenty pigs were randomly selected from each treatment at the end of experiment period and backfat thickness and LMP measurements were performed using a real time ultrasound instrument (Piglog 105, SFK Technology, Herlev, Denmark).

\section{Meat quality}

Five pigs of each treatment were slaughtered at the end of 22 th wk. After chilling at $2^{\circ} \mathrm{C}$ for $24 \mathrm{~h}$, one 2.54-cm-thick longissimus muscle sample was abstained at the 10th rib (right side of the carcass). The reflectance spectrometry measurements of lightness ( $\left.\mathrm{L}^{*}\right)$, redness (a*) and yellowness $\left(b^{*}\right)$ values were determined by MinoltaCR410 chroma meter (Konica Minolta Sensing, Inc., Osaka, Japan). Sensory evaluation (color, marbling and firmness scores) was evaluated according to National Pork Producers Council standards (NPPC 1991). Drip loss was determined as a percentage of the original weight using $2 \mathrm{~g}$ of meat sample 
$\mathrm{OH}$ et al., Effects of organic acids and essential oils in weaning to finishing pigs

according to the method of Honikel (1998). The weight of each sample was taken before and after cooking to determine cooking loss, which was defined as the cooked weight devided by uncooked weight multiplied by 100 . Duplicate $\mathrm{pH}$ values of each sample were measured via a glass-electrode pH meter (WTW pH 340-A, WTH Measurement Systems Inc. Ft. Myers, FL). Water holding capacity (WHC) was measured followed the guide of Kauffman et al. (1986). Longissimus muscle area (LMA) was measured by tracing the longissimus muscle surface at the 10th rib, which also used the above mentioned digitizing area-line sensor.

\section{Statistical Analysis}

All data were subjected to the statistical analysis as a randomized complete block design using the general linear model (GLM) procedures of SAS (SAS Inst. Inc., Cary, NC), and the pen was used as the experimental unit. The initial BW was used as a covariate for ADFI and ADG, and initial values was used as a covariate for blood profile. Before carrying out statistical analysis of the microbial counts, logarithmic conversion of the data was performed. Because of the design, linear and quadratic effects of treatment were assessed. Different among treatment means were determined using the Turkey's multiple range test with a $\mathrm{P}<$ 0.05 indicating a significance.

\section{RESULTS}

\section{Growth performance}

The pigs' body weight increased linearly $(\mathrm{P}=0.003,0.002,0.001)$ with increased MOE at the end of wks 6, 17, and 22 (Table 4). Moreover, pigs fed with the MOE2 diet had higher (P $<0.05$ ) body weight than did the pigs fed with the CON (control) diet at the end of wks 6, 17, and 22. From wk 0 to wk 6 , pigs fed with MOE2 had higher $(\mathrm{P}<0.05$; linear $\mathrm{P}=0.001)$ ADFI than did those fed with the CON or MOE1 diets. From wk 3 to wk 6, ADG increased linearly 
$(\mathrm{P}=0.040)$ with increased MOE. From wk 0 to wk 6, pigs fed the MOE2 diet had higher ADG than did pigs fed the $\mathrm{CON} \operatorname{diet}(\mathrm{P}<0.05$; linear $\mathrm{P}=0.006)$.

From wk 12 to wk 17, pigs fed the AV2 diet had higher ADG and G/F than did pigs fed the $\mathrm{CON} \operatorname{diet}(\mathrm{P}<0.05$; linear $\mathrm{P}=0.040, \mathrm{P}=0.024)$. From wk 17 to wk 22, pigs fed the $\mathrm{CON}$ diet had higher ADFI than did pigs fed the MOE $\operatorname{diet}(\mathrm{P}<0.05$; linear $\mathrm{P}=0.017$; quadratic $\mathrm{P}=$ 0.019). From wk 12 to wk 22, pigs fed the MOE2 diet had higher ADG, ADFI, and G/F ratio than did pigs fed the CON diet $(\mathrm{P}<0.05$; linear $\mathrm{P}=0.019,0.017,0.005)$.

Overall (wks 0 to 22), pigs fed the MOE2 diet had the highest ADG and G/F ratios of all treatments $(\mathrm{P}<0.05$; linear $\mathrm{P}=0.001,0.001)$.

\section{Nutrient retention}

At wk 3, the ATTD of DM increased in pigs fed with MOE2 $(\mathrm{P}<0.05)$ compared with pigs fed CON and MOE1 (Table 5). Pigs fed the MOE2 diet had higher ATTD of DM than did pigs fed the CON and MOE1 diets $(\mathrm{P}<0.05$; linear $\mathrm{P}=0.011)$. At wk 6 , the ATTD of DM increased $(\mathrm{P}<0.05$; linear $\mathrm{P}=0.007)$ in the MOE2 treatment.

\section{Blood profiles}

At wk 6, pigs fed the MOE1 diet had higher RBC concentrations than did pigs fed the MOE2 diet $(\mathrm{P}<0.05$; quadratic $\mathrm{P}=0.020)$ (Table 6$).$ IgG concentration was higher $(\mathrm{P}<0.05$; linear $\mathrm{P}=0.027$ ) in pigs fed the MOE2 diet than in those fed the CON diet. At wk 22, pigs fed the MOE1 diet had higher RBC concentrations than did pigs fed the MOE2 $\operatorname{diet}(\mathrm{P}<0.05$; quadratic $\mathrm{P}=0.030)$.

\section{Fecal microflora}


At wk 6, fecal Lactobacillus concentration increased $(\mathrm{P}<0.05$; linear $\mathrm{P}=0.044$; quadratic $\mathrm{P}=0.045)$ in MOE2 (Table 7).

\section{Carcass traits}

We observed no significant differences $(\mathrm{P}>0.05)$ in backfat thickness or LMP among treatments (Table 8).

\section{Meat quality}

The meat color $\left(\mathrm{a}^{*}\right)$ drip loss on $\mathrm{d} 7$ decreased $(\mathrm{P}<0.05$; linear $\mathrm{P}=0.028$, quadratic $\mathrm{P}=$ 0.026) in MOE1, MOE2 treatments compared with CON treatment (Table 9). We also observed no significant differences $(\mathrm{P}>0.05)$ in meat color, cooking loss, sensory evaluation, $\mathrm{pH}$, water holding capacity. or longissimus muscle area among treatments. 
$\mathrm{OH}$ et al., Effects of organic acids and essential oils in weaning to finishing pigs

\section{DISCUSSION}

In this study, adding MOE to pig feed improved growth performance during the overall period and improved nutrient retention and fecal microflora during the weanling period. Constituent OA promotes nutrient retention by lowering the $\mathrm{pH}$ of the gastrointestinal tract (Busser et al., 2011); in particular, it helps to digest crude fiber and non-starch polysaccharide and carbohydrate with essential oil (Gerritesen et al., 2010). Lim et al. (2015) reported that most OA was absorbed in intestinal epithelial cells by passive diffusion. Moreover, OA can be used in metabolic pathways for TCA cycle and ATP generation (Lin et al., 2017). As the MOE essential oil, thymol is extracted from plants and improves feed efficiency and changes in gut luminal metabolites (Grilli et al., 2010). Microencapsulation can deliver nutrients throughout the gastrointestinal tract and protect amino acids and proteins (Piva et al, 1997). For this reason, microencapsulation could increase the effects of OA and EO (Cho et al., 2014).

In the present study, treatment linearly increases ADFI and ADG during the weanling to growing and growing to finishing periods, and similar results were found in other studies; OA and EO improved ADG and G:F at end of week 6 (Xu et al., 2018; Huang et al., 2010; Hong et al., 2004; Cho et al., 2006). Upadhaya et al. (2014) demonstrated that OA reduced pathogenic microbes and allowed the host to use energy required for microbial metabolism. In another study, adding vanillin, an EO, improved feed intake and ADG (Gallage et al., 2014). In our previous study, we conducted similar experiments with only finishing pigs (Cho et al., 2014), and the microencapsulated mixture significantly improved growth performance. In this study, the ATTD of DM increased linearly $(\mathrm{P}=0.011,0.007)$ at week 3 and week 6 , but there were no significant differences during other periods; there were also no significant differences in nitrogen and energy retention. However, many other studies showed increased nitrogen retention in pigs fed OA and EO (Cho et al., 2006; Kwak et al., 2017; Y. T. Xu et al., 
$\mathrm{OH}$ et al., Effects of organic acids and essential oils in weaning to finishing pigs

2018) by lowering gastrointestinal tract $\mathrm{pH}$, which increased the activity of digestive enzymes such as pepsin and trypsin (Burt, 2004; Long et al., 2018). In our previous study (Cho et al., 2014), energy retention nalso increased linearly $(\mathrm{P}<0.05)$, but we could not find any significant difference in this study.

In blood profiles, IgG concentration increased linearly $(\mathrm{P}=0.027)$ at week $6 . \mathrm{OA}$ and $\mathrm{EO}$ function to enhance immune system and antibacterial activity (Wenk, 2003). In the present study, red blood cell $(\mathrm{RBC})$ concentrations showed quadratic effects $(\mathrm{P}=0.020, \mathrm{P}=0.030)$ with MOE density at weeks 6 and 22. However, Hong et al. (2004) and Lien et al. (2006) reported that essential oil and organic acid supplementation did not affect RBC concentration. Therefore, we need additional studies about the effects of OA and EO on pigs' RBC concentrations.

In other studies of pigs fed with OA and essential oils, authors also reported that OA prevents growing gut microbial pathogens without damaging beneficial bacteria such as Lactobacillus (Øverland et al., 2008; Schöner, 2001; Long et al., 2018). In our study, however, the effect of MOE on fecal microflora such as E. coli was not significantly different. Fecal Lactobacillus increased linearly $(\mathrm{P}=0.044)$ at 6 weeks, and similarly, in a different study, OA and essential oil improved Lactobacillus in weanling piglets (Y. K. Xu et al., 2017).

Our study showed no effects of OA or EO on the pigs' carcass traits, similar to our previous study findings (Cho et al., 2014). However, we did find significant differences in meat color and drip loss in terms of meat quality, whereas in our previous study, there were no effects on meat quality (Cho et al., 2014). In this study, the redness of the meat ( $\left.{ }^{*}\right)$ decreased linearly in the treatment groups, and low redness has the disadvantage that consumers prefer darker meat. However, this finding was different from that in our previous study (Cho et al., 2014), and thus it seems that more research is required. Sorbic and para-aminobenzoic acids used as antimicrobial agents in meat packing reduce drip loss (Cutter, 1999), but we also found no 
significant difference in our previous study (Cho et al., 2014), so again, more research is needed.

\section{CONCLUSION}

Supplementing the diets with $0.2 \%$ MOE could increase BW, ADFI, ADG and G/F linearly; also MOE had a positive effect on ATTD of DM. It was observed that supplementing the diets with $0.2 \% \mathrm{MOE}$ increased the levels of $\mathrm{RBC}$ and $\mathrm{IgG}$ and also they had a positive influence on increasing fecal lactobacillus counts. Moreover, MOE had a significant effect on reducing meat color $\left(\mathrm{a}^{*}\right)$ and drip loss.

\section{ACKNOWLEDGEMENT}

This work was carried out with the support of "Cooperative Research program for Agriculture Science \& Technology Development (Project No. PJ01261502)” Rural Development Administration Republic of Korea.

\section{REFERENCE}

Øverland, M., Kjos, N. P., Borg, M., Skjerve, E., \&Sørum, H. 2008. Organic acids in diets for entire male pigs: Effect on skatole level, microbiota in digesta, and growth performance. Livestock Science, 115: 169-178.

Association of Official Analytical Chemists. 2000. Official method of analysis. 16th Edition.AOAC, Washington, D. C.

\section{Busser EVD, Dewulf J, Zutter LD, Haesebrouck F, Callens J, Meyns T, Maes W, Maes}

D. 2011. Effect of administration of organic acids in drinking water on fecal shedding of E.coli performance parameters and health in nursery pigs. Vet J,188: 184-188 
Burt, S.2004. Essential oils: Their antibacterial properties and potential applications in foodA review. Int. J. Food Microbiol.94:223-253.

Canibe, N.,O. Højberg,S. Højsgaard,and B. B. Jensen.2005.Feed physical form and formic acid addition to the feed affect the gastrointestinal ecology and growth performance of growing pigs. J. Anim.Sci.83:1287-1302.

Cho, J. H., Y. J. Chen, B. J. Min, H. J. Kim, O. S. Kwon, K. S. Shon, I. H. Kim, S. J. Kim, and A.Asamer. 2006. Effects of Essential oils supplementation on growth performance, IgGconcentration and fecal noxious gas concentration of weaned pigs. Asian-Aust. J. Anim.Sci. 19:80-85.

Cho, J. H., Song, M. H., \& Kim, I. H. 2014. Effect of microencapsulated blends of organic acids and essential oils supplementation on growth performance and nutrient digestibility in finishing pigs. RevistaColombiana de CienciasPecuarias, 27: 264-272.

Cutter,C.N.1999. The effectiveness of triclosan-incorporated plastic against bacteria on beef surfaces. Journal of Food Protection, 62: 474-479.

Falcone, P., Speranza, B., Del Nobile, M. A., Corbo, M. R., \&Sinigaglia, M. 2005. A study on the antimicrobial activity of thymol intended as a natural preservative. Journal of food protection, 68: 1664-1670.

Feton, T. W., and M. Fenton. 1979. An improved method for chromic oxide determination in feed and feces. Can. J. Sci. 59: 631-634.Archivos.De.Zootecnia.54:311.

Gallage, N. J., Hansen, E. H., Kannangara, R., Olsen, C. E., Motawia, M. S., Jørgensen, K., ... \&Møller, B. L. 2014. Vanillin formation from ferulic acid in Vanilla planifolia is catalysed by a single enzyme. Nature communications, $\mathbf{5}$.

Gerritsen R, van Dijk AJ, Rethy k, Bikker P. 2010. The effect of blends of organic acids on apparent faecal digestibility in piglets. Livest Sci. 134:246-248 
$\mathrm{OH}$ et al., Effects of organic acids and essential oils in weaning to finishing pigs

Grilli, E.,M. R. Messina, M. Tedeschi,and A.Piva. 2010.Feeding a microencapsulated blend of organic acids and nature identical compounds to weaning pigs improved growth performance and intestinal metabolism. Livest.Sci.133:173-175.

Goksoy, E. O., M. Aksit, and S. Kirkan. 2010. The effects of organic acid and origanumonites supplementations on some physical and microbial characteristics of broiler meat obtained from broilers kept under seasonal heat stress. KankasUniv Vet FakDerg; 16:S41-S46.

Hong, J. W., Kim, I. H., Kwon, O. S., Min, B. J., Lee, W. B., \& Shon, K. S. 2004. Influences of plant extract supplementation on performance and blood characteristics in weaned pigs. ASIAN AUSTRALASIAN JOURNAL OF ANIMAL SCIENCES, 17: 374-378. Honikel, K.O., 1998. Reference methods for the assessment of physical characteristics of meat. Meat. Sci. 49 :447-457.

\section{Huang, Y., Yoo, J. S., Kim, H. J., Wang, Y., Chen, Y. J., Cho, J. H., \& Kim, I. H. 2010.}

Effects of dietary supplementation with blended essential oils on growth performance, nutrient digestibility, blood profiles and fecal characteristics in weanling pigs. AsianAustralasian Journal of Animal Sciences, 23: 607.

Kwak, W. G., Park, I. H., Yun, W., Lee, J. H., Lee, C. H., Oh, S. Y., ... \& Kim, G. S. 2017. Effects of various additives to enhance growth performance, blood profiles, and reduce malodour emissions in growing pigs. South African Journal of Animal Science, 47: 535-541. Kelley, T. R.,O. C.Pancorbo,W. C.Merka,and H. M. Barnhart.1998.Antibiotic resistance of litter isolates. Poult. Sci.77:243-247.

Lien, T. F., Horng, Y. M., \& Wu, C. P. 2007. Feasibility of replacing antibiotic feed promoters with the Chinese traditional herbal medicine Bazhen in weaned piglets. Livestock Science, 107: 97-102. 
Lim, C., Lückstädt, C., Webster, C.D., Kesius, P., 2015. Organic acids and their salts. In: Lee, C.S., Lim, C., Gatlin, D.M., Webster, C. (Eds.), Dietary Nutrients, Additives, and Fish Health. Willey-Blackwell, Hoboken, NJ, USA, 305-320

Lin, Y. H., \& Cheng, M. Y. 2017. Effects of dietary organic acid supplementation on the growth, nutrient digestibility and intestinal histology of the giant grouper Epinepheluslanceolatus fed a diet with soybean meal. Aquaculture, 469: 106-111.

Long, S. F., Xu, Y. T., Pan, L., Wang, Q. Q., Wang, C. L., Wu, J. Y., ... \& Piao, X. S.2018. Mixed organic acids as antibiotic substitutes improve performance, serum immunity, intestinal morphology and microbiota for weaned piglets. Animal Feed Science and Technology, 235: 23-32.

National Pork Producers Council. 1991. Procedures to Evaluate Market Hogs ( $3^{\text {rd }}$ Ed). N PPC, Des Moines. IA.

National ResearchCouncil.2012. Nutrient requirement of pigs (11th Ed.) National Research Council, Academy Press. Washington, DC.

Piva, A., Anfossi, P., Meola, E., Pietri, A., Panciroli, A., Bertuzzi, T. and Formigoni, A. 1997.Effect of microencapsulation on absorption processes in swine. Livestock Production Science.51: 53-61.

Piva,A.,V. Pizzamiglio,M. Morlacchini,M. Tedeschi,and G.Piva. 2007. Lipid microencapsulation allows slow release of organic acids and natural identical flavors along the swine intestine. J. Anim.Sci.85:486-493.

Schöner, F.J., 2001. Nutritional effects of organic acids. Cah. Options Méditerr. 54: 55-61. Simonson, R.R. 2004. Antimicrobial properties of herbs and spices and their potential use in diets for pigs. Newport Laboratories, Inc. submitted to CRIS. 
$\mathrm{OH}$ et al., Effects of organic acids and essential oils in weaning to finishing pigs

Upadhaya, S. D., Lee, K. Y., \& Kim, I. H. 2014. Influence of protected organic acid blends and diets with different nutrient densities on growth performance, nutrient digestibility and faecal noxious gas emission in growing pigs. VeterinarniMedicina, 59(10).

Wang, J. P, J. S. Yoo, J. H. Lee, H. D. Jang, H. J. Kim, S. O. Shin, S. I. Seong, and I. H.

Kim. 2009. Effect of phenyllactic acid on growth performance, nutrient digestibility, microbial shedding, and blood profile in pigs. J. Anim. Sci.87:3235-3243.

Wenk, C. 2003. Herbs and botanicals as feed additives in monogastric animals. Asian Australasian Journal of Animal Sciences, 16: 282-289.

Williams. C. H., D. J. David, and O. Iismaa. 1962. The determination of chromic oxide in faeces samples by atomic absorption spectrophotometry. J. Agric. Sci. 59:381-385.

Windisch, W., K. Schedle, C. Plitzner, and A.Kroismayr. 2008. Use of phytogenic products as feed additives for swine and poultry. J. Anim. Sci.86:140-148.

Xu, Y. T., Liu, L., Long, S. F., Pan, L., \& Piao, X. S. 2018. Effect of organic acids and essential oils on performance, intestinal health and digestive enzyme activities of weaned pigs. Animal Feed Science and Technology, 235: 110-119. 
Table 1. Compositions of the basal weanling diets (as-fed basis)

\begin{tabular}{|c|c|c|c|}
\hline Items & Day1 to 7 & Day8 to 21 & Day 22 to 42 \\
\hline \multicolumn{4}{|l|}{ Ingredient, \% } \\
\hline Extruded corn & 29.18 & 44.49 & 61.97 \\
\hline Soybean meal, $48 \% \mathrm{CP}^{\mathrm{a}}$ & 6.94 & 16.20 & 25.30 \\
\hline Fermented soybean meal, $45 \% \mathrm{CP}$ & 10.00 & 5.00 & 2.50 \\
\hline Fish meal, $66 \% \mathrm{CP}$ & 5.00 & 3.50 & - \\
\hline Soy oil & 3.65 & 2.55 & 1.05 \\
\hline Lactose & 15.30 & 8.30 & - \\
\hline Whey & 15.00 & 10.00 & 5.00 \\
\hline Monocalcium phosphate & 1.45 & - & - \\
\hline Dicalcium phosphate & & 1.50 & 1.50 \\
\hline Sugar & 5.00 & 3.00 & - \\
\hline Plasma powder & 6.00 & 3.00 & - \\
\hline L-Lysine- $\mathrm{HCl}, 78 \%$ & 0.29 & 0.39 & 0.46 \\
\hline DL-Methionine, $50 \%$ & 0.32 & 0.30 & 0.24 \\
\hline L-Threonine, $89 \%$ & 0.13 & 0.19 & 0.20 \\
\hline Choline chloride, $25 \%$ & 0.20 & 0.10 & 0.10 \\
\hline Vitamin premix $^{\mathrm{b}}$ & 0.10 & 0.10 & 0.10 \\
\hline Trace mineral premix ${ }^{\mathrm{c}}$ & 0.20 & 0.20 & 0.20 \\
\hline Limestone & 1.24 & 0.98 & 1.13 \\
\hline Salt & - & 0.20 & 0.25 \\
\hline Total & 100.00 & 100.00 & 100.00 \\
\hline
\end{tabular}

Analyzed composition, \% 
$\mathrm{OH}$ et al., Effects of organic acids and essential oils in weaning to finishing pigs

\begin{tabular}{lccc} 
ME, kcal $/ \mathrm{kg}$ & 3,591 & 3,534 & 3,409 \\
$\mathrm{CP}$ & 21.12 & 19.87 & 19.07 \\
Lys & 1.65 & 1.53 & 1.32 \\
$\mathrm{Met}$ & 0.61 & 0.60 & 0.55 \\
$\mathrm{Ca}$ & 0.97 & 0.91 & 0.87 \\
$\mathrm{P}$ & 0.82 & 0.73 & 0.67 \\
\hline${ }^{\mathrm{a}} \mathrm{CP}$ crude protein & & &
\end{tabular}

${ }^{\mathrm{a}} \mathrm{CP}$, crude protein.

${ }^{\mathrm{b}}$ Provided per kg of complete diet: vitamin A, 11,025 IU; vitamin $\mathrm{D}_{3}, 1,103 \mathrm{IU}$; vitamin $\mathrm{E}, 44$ IU; vitamin K, $4.4 \mathrm{mg}$; riboflavin, $8.3 \mathrm{mg}$; niacin, $50 \mathrm{mg}$; thiamine, $4 \mathrm{mg}$; d-pantothenic, 29 mg; choline, $166 \mathrm{mg}$; and vitamin $\mathrm{B}_{12}, 33 \mu \mathrm{g}$.

${ }^{c}$ Provided per kg of complete diet: $\mathrm{Cu}\left(\right.$ as $\left.\mathrm{CuSO}_{4} \cdot 5 \mathrm{H}_{2} \mathrm{O}\right), 12 \mathrm{mg}$; $\mathrm{Zn}\left(\right.$ as $\left.\mathrm{ZnSO}_{4}\right), 85 \mathrm{mg}$; $\mathrm{Mn}$ (as $\mathrm{MnO}_{2}$ ), $8 \mathrm{mg}$; I (as KI), $0.28 \mathrm{mg}$; and $\mathrm{Se}\left(\right.$ as $\mathrm{Na}_{2} \mathrm{SeO}_{3} \cdot 5 \mathrm{H}_{2} \mathrm{O}$ ), $0.15 \mathrm{mg}$. 
Table 2. Composition of the basal growing diets (as-fed basis)

\begin{tabular}{|c|c|}
\hline Items & Content \\
\hline \multicolumn{2}{|l|}{ Ingredients, $\mathrm{g} / \mathrm{kg}$} \\
\hline Corn & 55.38 \\
\hline Soybean meal & 33.43 \\
\hline Molasses & 2.50 \\
\hline Animal fat & 5.33 \\
\hline Difluorinated phosphate & 1.93 \\
\hline Limestone & 0.78 \\
\hline L-lysine $\mathrm{HCl}$ & 0.17 \\
\hline Trace mineral premix ${ }^{a}$ & 0.10 \\
\hline Vitamin premix $^{\mathrm{b}}$ & 0.12 \\
\hline Salt & 0.20 \\
\hline DL-methionine & 0.03 \\
\hline Choline chloride & 0.03 \\
\hline \multicolumn{2}{|l|}{ Analyzed composition } \\
\hline $\mathrm{ME}, \mathrm{Kcal} / \mathrm{kg}$ & 3,372 \\
\hline $\mathrm{CP}, \%$ & 19.65 \\
\hline $\mathrm{Ca}, \%$ & 0.87 \\
\hline $\mathrm{P}, \%$ & 0.76 \\
\hline
\end{tabular}

${ }^{a}$ Provided per kg of complete diet: $12.5 \mathrm{mg} \mathrm{Mn}, 179 \mathrm{mg} \mathrm{Zn,} 140 \mathrm{mg} \mathrm{Cu}, 0.5 \mathrm{mg}$ I and $0.4 \mathrm{mg}$ Se.

${ }^{b}$ Provided per kg of complete diet: 20,000 IU of vitamin A; 4,000 IU of vitamin D3; 80 IU of vitamin E; $16 \mathrm{mg}$ of vitamin $\mathrm{K} 3 ; 4 \mathrm{mg}$ of thiamine, $20 \mathrm{mg}$ of riboflavin; $6 \mathrm{mg}$ of 
$\mathrm{OH}$ et al., Effects of organic acids and essential oils in weaning to finishing pigs

pyridoxine; $0.08 \mathrm{mg}$ of vitamin $\mathrm{B} 12 ; 120 \mathrm{mg}$ of niacin; $50 \mathrm{mg}$ of Ca-pantothenate; 2 $\mathrm{mg}$ of folic acid and $0.08 \mathrm{mg}$ of biotin. 
Table 3. Composition of basal finishing diets (as-fed basis)

\begin{tabular}{|c|c|}
\hline Items & Content \\
\hline \multicolumn{2}{|l|}{ Ingredients, $\%$} \\
\hline Ground corn & 59.30 \\
\hline Soybean meal (CP 47.5\%) & 31.68 \\
\hline Tallow & 2.79 \\
\hline Molasses & 3.00 \\
\hline Limestone & 0.36 \\
\hline Phosphorus & 1.84 \\
\hline Salt & 0.15 \\
\hline L-Lys $\cdot \mathrm{HCl}(78 \%)$ & 0.27 \\
\hline DL-Met $(50 \%)$ & 0.10 \\
\hline L-Thr(89\%) & 0.07 \\
\hline Choline chloride $(25 \%)$ & 0.11 \\
\hline Vitamin premix $^{\mathrm{a}}$ & 0.13 \\
\hline Trace mineral premix ${ }^{\mathrm{b}}$ & 0.2 \\
\hline \multicolumn{2}{|l|}{ Analyzed composition } \\
\hline $\mathrm{ME}, \mathrm{kcal} / \mathrm{kg}$ & 3,311 \\
\hline $\mathrm{CP}, \%$ & 17.41 \\
\hline $\mathrm{Ca}$ & 0.78 \\
\hline Available P & 0.61 \\
\hline Lys & 1.09 \\
\hline
\end{tabular}

${ }^{\mathrm{a}}$ Provided per kg of complete diet: vitamin A, $4000 \mathrm{IU}$; vitamin $\mathrm{D}_{3}, 800 \mathrm{IU}$; vitamin $\mathrm{E}$,

$171 \mathrm{IU}$; vitamin K, $2 \mathrm{mg}$; riboflavin, $4 \mathrm{mg}$; niacin, $20 \mathrm{mg}$; thiamine, $4 \mathrm{mg}$; d- 
$\mathrm{OH}$ et al., Effects of organic acids and essential oils in weaning to finishing pigs

pantothenic, $11 \mathrm{mg}$; choline, $166 \mathrm{mg}$; biotin, $0.08 \mathrm{mg}$; and vitamin $\mathrm{B}_{12}, 16 \mu \mathrm{g}$.

${ }^{b}$ Provided per kg of complete diet: $\mathrm{Cu}\left(\right.$ as $\left.\mathrm{CuSO}_{4} \cdot 5 \mathrm{H}_{2} \mathrm{O}\right), 15 \mathrm{mg}$; $\mathrm{Fe}\left(\right.$ as $\left.\mathrm{FeSO}_{4} \cdot 7 \mathrm{H}_{2} \mathrm{O}\right)$,

$80 \mathrm{mg}$; $\mathrm{Zn}\left(\right.$ as $\left.\mathrm{ZnSO}_{4}\right), 56 \mathrm{mg}$; $\mathrm{Mn}\left(\mathrm{MnO}_{2}\right), 74 \mathrm{mg}$; I (as KI), $0.3 \mathrm{mg}$; Co (as

$\left.\mathrm{CoSO}_{4} \cdot 5 \mathrm{H}_{2} \mathrm{O}\right), 0.5 \mathrm{mg}$; and $\mathrm{Se}\left(\right.$ as $\left.\mathrm{Na}_{2} \mathrm{SeO}_{3} \cdot 5 \mathrm{H}_{2} \mathrm{O}\right), 0.4 \mathrm{mg}$. 
Table 4. The effect of microencapsulated complex of organic acids and essential oils supplementation on growth performance in weaning to finishing pigs. ${ }^{\mathrm{a}}$

\begin{tabular}{|c|c|c|c|c|c|c|}
\hline Item & $\mathrm{CON}$ & MOE1 & MOE2 & $\mathrm{SEM}^{\mathrm{b}}$ & Linear $^{\mathrm{c}}$ & Quadratic $^{c}$ \\
\hline \multicolumn{7}{|l|}{ Body } \\
\hline \multicolumn{7}{|c|}{ weight, } \\
\hline \multicolumn{7}{|l|}{$\mathrm{kg}$} \\
\hline Initial & 6.47 & 6.47 & 6.48 & 0.05 & 0.924 & 0.951 \\
\hline $1 \mathrm{wks}$ & 7.82 & 7.88 & 8 & 0.07 & 0.095 & 0.713 \\
\hline $3 w k s$ & 13.94 & 14.21 & 14.4 & 0.16 & 0.056 & 0.821 \\
\hline $6 \mathrm{wks}$ & $25.97 b$ & $26.41 a b$ & $27.06 a$ & 0.24 & 0.003 & 0.780 \\
\hline $12 \mathrm{wks}$ & 54.66 & 55.3 & 56.96 & 0.89 & 0.079 & 0.642 \\
\hline $17 \mathrm{wks}$ & $83.36 b$ & $84.56 b$ & $87.73 a$ & 0.95 & 0.002 & 0.408 \\
\hline $22 \mathrm{wks}$ & $109.29 b$ & $111.65 b$ & $114.89 a$ & 1.10 & 0.001 & 0.734 \\
\hline \multicolumn{7}{|l|}{ Week 0-1 } \\
\hline ADG, $g$ & 193 & 201 & 217 & 8.66 & 0.061 & 0.703 \\
\hline ADFI, $g$ & $234 c$ & $252 b$ & $268 a$ & 2.57 & 0.001 & 0.785 \\
\hline $\mathrm{G} / \mathrm{F}$ & 0.825 & 0.798 & 0.81 & 0.034 & 0.710 & 0.679 \\
\hline \multicolumn{7}{|l|}{ Week 1-3 } \\
\hline ADG, $g$ & 437 & 452 & 457 & 9.82 & 0.172 & 0.651 \\
\hline ADFI, $g$ & $637 b$ & $631 b$ & $648 a$ & 3.31 & 0.010 & 0.006 \\
\hline $\mathrm{G} / \mathrm{F}$ & 0.686 & 0.716 & 0.705 & 0.016 & 0.453 & 0.269 \\
\hline \multicolumn{7}{|l|}{ Week 3-6 } \\
\hline ADG, $\mathrm{g}$ & $573 b$ & $581 a b$ & $603 a$ & 9.34 & 0.040 & 0.604 \\
\hline ADFI, $g$ & $961 b$ & $969 b$ & $993 a$ & 6.83 & 0.002 & 0.369 \\
\hline $\mathrm{G} / \mathrm{F}$ & 0.596 & 0.6 & 0.607 & 0.009 & 0.504 & 0.932 \\
\hline
\end{tabular}

Week 0-6 
$\mathrm{OH}$ et al., Effects of organic acids and essential oils in weaning to finishing pigs

$\begin{array}{ccccccc}\text { ADG, g } & 464 b & 475 a b & 490 a & 5.98 & 0.006 & 0.803 \\ \text { ADFI, g } & 732 b & 737 b & 757 a & 3.92 & 0.001 & 0.123 \\ \text { G/F } & 0.634 & 0.645 & 0.647 & 0.008 & 0.341 & 0.678\end{array}$

Week 6-12

ADG, $g$

683

688

712

19.96

0.302

0.677

ADFI, $g$

1467

1469

1460

3.69

0.267

0.220

G/F

0.466

0.468

0.488

0.013

0.224

0.571

Week 12-17

$\begin{array}{ccccccc}\text { ADG, g } & 820 b & 836 a b & 879 a & 19.65 & 0.040 & 0.592 \\ \text { ADFI, g } & 1939 & 1938 & 1904 & 17.07 & 0.220 & 0.490 \\ \text { G/F } & 0.423 b & 0.431 a b & 0.462 a & 0.012 & 0.024 & 0.500\end{array}$

Week 17-22

$\begin{array}{ccccccc}\text { ADG, g } & 741 & 774 & 776 & 21.71 & 0.248 & 0.592 \\ \text { ADFI, g } & 2619 a & 2579 b & 2589 b & 8.49 & 0.017 & 0.019 \\ \text { G/F } & 0.283 & 0.3 & 0.3 & 0.008 & 0.153 & 0.420\end{array}$

Week 12-22

$\begin{array}{ccccccc}\text { ADG, g } & 781 b & 805 a b & 828 a & 13.85 & 0.019 & 0.967 \\ \text { ADFI, g } & 2279 a & 2259 a b & 2247 b & 8.57 & 0.017 & 0.625 \\ \text { G/F } & 0.343 b & 0.356 a b & 0.368 a & 0.006 & 0.005 & 0.905\end{array}$

Week 0-22

$\begin{array}{ccccccr}\text { ADG, g } & 668 b & 683 b & 704 a & 7.30 & 0.001 & 0.740 \\ \text { ADFI, g } & 1635 & 1628 & 1626 & 4.50 & 0.210 & 0.605 \\ \text { G/F } & 0.409 b & 0.42 b & 0.433 a & 0.004 & 0.001 & 0.819\end{array}$

Note: Means in the same row with different superscripts differ $(\mathrm{P}<0.05)$.

${ }^{a}$ Abbreviation: CON, basal diet; MOE1, basal $+0.1 \%$ (weanling phase) $\& 0.025 \%$ (growing finishing phase) microencapsulated complex of organic acids and essential oils; MOE2, basal + 
$\mathrm{OH}$ et al., Effects of organic acids and essential oils in weaning to finishing pigs

$0.2 \%$ (weanling phase) \& $0.05 \%$ (growing finishing phase) microencapsulated complex of organic acids and essential oils.

${ }^{\mathrm{b}} \mathrm{Standard}$ error.

${ }^{\mathrm{c}} \mathrm{CON}$ vs MOE 1 vs MOE2. 
$\mathrm{OH}$ et al., Effects of organic acids and essential oils in weaning to finishing pigs

Table 5. Effects of microencapsulated complex of organic acids and essential oils supplementation on nutrient retentionin weaning to finishing pigs $^{\mathrm{a}}$

\begin{tabular}{|c|c|c|c|c|c|c|}
\hline Item $\quad, \%$ & $\mathrm{CON}$ & MOE1 & MOE2 & $\mathrm{SE}^{\mathrm{b}}$ & Linear $^{c}$ & Quadratic $^{c}$ \\
\hline \multicolumn{7}{|l|}{ Week 3} \\
\hline Dry matter & $81.82 b$ & $82.21 b$ & $83.67 a$ & 0.46 & 0.011 & 0.360 \\
\hline Nitrogen & 78.87 & 78.82 & 80.47 & 0.85 & 0.198 & 0.422 \\
\hline Energy & 80.26 & 80.5 & 81.16 & 0.51 & 0.230 & 0.742 \\
\hline \multicolumn{7}{|l|}{ Week 6} \\
\hline Dry matter & $72.29 b$ & $74.53 a b$ & $76.63 a$ & 1.03 & 0.007 & 0.960 \\
\hline Nitrogen & 74.08 & 75.13 & 76.84 & 1.00 & 0.066 & 0.788 \\
\hline Energy & 74.61 & 75.97 & 76.51 & 0.84 & 0.124 & 0.692 \\
\hline \multicolumn{7}{|l|}{ Week 12} \\
\hline Dry matter & 73.1 & 73.57 & 74.36 & 0.48 & 0.079 & 0.787 \\
\hline Nitrogen & 72.26 & 72.21 & 72.2 & 0.40 & 0.925 & 0.965 \\
\hline Energy & 71.34 & 72.18 & 72.23 & 0.39 & 0.123 & 0.417 \\
\hline \multicolumn{7}{|l|}{ Week 22} \\
\hline Dry matter & 72.06 & 72.29 & 73.65 & 0.75 & 0.207 & 0.570 \\
\hline Nitrogen & 71.54 & 71.59 & 72.46 & 0.83 & 0.485 & 0.721 \\
\hline Energy & 70.88 & 71.26 & 73.04 & 0.98 & 0.128 & 0.555 \\
\hline
\end{tabular}

Note: Means in the same row with different superscripts differ $(\mathrm{P}<0.05)$.

${ }^{a}$ Abbreviation: CON, basal diet; MOE1, basal $+0.1 \%$ (weanling phase) \& $0.025 \%$ (growing finishing phase) microencapsulated complex of organic acids and essential oils; MOE2, basal $+0.2 \%$ (weanling phase) \& $0.05 \%$ (growing finishing phase) microencapsulated complex of organic acids and essential oils.

${ }^{\mathrm{b}}$ Standard error.

${ }^{\mathrm{c}} \mathrm{CON}$ vs MOE 1 vs MOE2. 
Table 6. The effect of microencapsulated complex of organic acids and essential oils supplementation on the blood profiles in weanling to finishing pigs ${ }^{\mathrm{a}}$

\begin{tabular}{|c|c|c|c|c|c|c|}
\hline Item & $\mathrm{CON}$ & MOE1 & MOE2 & $\mathrm{SE}^{\mathrm{b}}$ & Linear $^{\mathrm{c}}$ & Quadratic $^{c}$ \\
\hline \multicolumn{7}{|l|}{ Week 6} \\
\hline $\mathrm{WBC}, 10^{3} / \mu \ell$ & 16.9 & 17.45 & 16.73 & 1.14 & 0.916 & 0.658 \\
\hline $\mathrm{RBC}, 10^{6} / \mu \ell$ & $7.29 a b$ & $7.8 a$ & $7.07 b$ & 0.19 & 0.447 & 0.020 \\
\hline Lymphocyte, \% & 52.9 & 57.8 & 57.9 & 3.68 & 0.354 & 0.600 \\
\hline $\mathrm{IgG}, \mathrm{mg} / \mathrm{dL}$ & $270 b$ & $281 a b$ & $313 a$ & 12.1 & 0.027 & 0.833 \\
\hline \multicolumn{7}{|l|}{ Week 12} \\
\hline WBC, $10^{3} / \mu \ell$ & 18.03 & 18.27 & 17.93 & 0.79 & 0.932 & 0.774 \\
\hline $\mathrm{RBC}, 10^{6} / \mu \ell$ & 6.27 & 6.69 & 6.63 & 0.28 & 0.380 & 0.508 \\
\hline Lymphocyte, \% & 42.2 & 42.2 & 44.1 & 6.61 & 0.846 & 0.905 \\
\hline $\mathrm{IgG}, \mathrm{mg} / \mathrm{dL}$ & 517 & 583 & & 44.42 & 0.084 & 0.898 \\
\hline \multicolumn{7}{|l|}{ Week 22} \\
\hline WBC, $10^{3} / \mu \ell$ & 19.02 & 19.53 & 19.04 & 0.96 & 0.986 & 0.679 \\
\hline $\mathrm{RBC}, 10^{6} / \mu \ell$ & $7.08 a b$ & $7.54 a$ & $6.57 b$ & 0.24 & 0.156 & 0.030 \\
\hline Lymphocyte, \% & 42.1 & 48.5 & 41.9 & 6.01 & 0.982 & 0.393 \\
\hline
\end{tabular}

Note: Means in the same row with different superscripts differ $(\mathrm{P}<0.05)$.

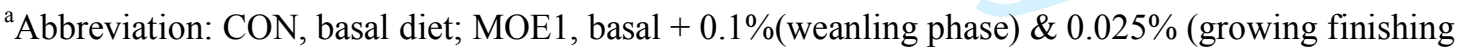
phase) microencapsulated complex of organic acids and essential oils; AV2, basal $+0.2 \%$ (weanling phase) $\& 0.05 \%$ (growing finishing phase) microencapsulated complex of organic acids and essential oils.

${ }^{\mathrm{b}}$ Standard error.

${ }^{\mathrm{c}} \mathrm{CON}$ vs MOE1 vs MOE2. 
$\mathrm{OH}$ et al., Effects of organic acids and essential oils in weaning to finishing pigs

Table 7. Effect of microencapsulated complex of organic acids and essential oils supplementation on fecal microflora in weanling to finishing pigs ${ }^{\mathrm{a}}$

\begin{tabular}{lcccccc}
\hline Item & CON & AV1 & AV2 & SE $^{\text {b }}$ & Linear $^{\text {c }}$ & Quadratic $^{\text {c }}$ \\
\hline Week 6 & & & & & & \\
Lactobacillus & $7.45 b$ & $7.52 b$ & $7.70 a$ & 0.05 & 0.044 & 0.045 \\
$\quad$ E.coli & 5.32 & 5.28 & 5.18 & 0.22 & 0.668 & 0.915 \\
Week 12 & & & & & & \\
Lactobacillus & 7.49 & 7.5 & 7.47 & 0.03 & 0.702 & 0.682 \\
$\quad$ E.coli & 6.06 & 6.18 & 6.19 & 0.05 & 0.108 & 0.366 \\
Week 22 & & & & & & \\
Lactobacillus & 7.46 & 7.51 & 7.48 & 0.02 & 0.471 & 0.154 \\
E.coli & 6.08 & 6.01 & 5.98 & 0.04 & 0.121 & 0.655 \\
\hline
\end{tabular}

Note: Means in the same row with different superscripts differ $(\mathrm{P}<0.05)$.

${ }^{a}$ Abbreviation: CON, basal diet; MOE1, basal $+0.1 \%$ (weanling phase) \& $0.025 \%$ (growing finishing phase) microencapsulated complex of organic acids and essential oils; AV2, basal $+0.2 \%$ (weanling phase) \& $0.05 \%$ (growing finishing phase) microencapsulated complex of organic acids and essential oils.

${ }^{\mathrm{b}}$ Standard error.

${ }^{c} \mathrm{CON}$ vs MOE1 vs MOE2. 
$\mathrm{OH}$ et al., Effects of organic acids and essential oils in weaning to finishing pigs

Table 8. Effect of microencapsulated complex of organic acids and essential oils supplementation on carcass traits in weanling to finishing pigs ${ }^{\mathrm{a}}$

\begin{tabular}{lcccccc}
\hline Item & CON & MOE1 & MOE2 & SE $^{\mathrm{b}}$ & Linear $^{\mathrm{c}}$ & Quadratic $^{\mathrm{c}}$ \\
\hline Backfat & & & & & & \\
$\quad$ thickness, & 21.50 & 22.40 & 22.40 & 0.38 & 0.117 & 0.361 \\
$\quad$ & & & & & \\
mm & 53.27 & 53.55 & 54.68 & 0.54 & 0.069 & 0.521 \\
LMP, \% & & & & & & \\
\end{tabular}

\footnotetext{
${ }^{a}$ Abbreviation: CON, basal diet; MOE1, basal + 0.1\%(weanling phase) \& 0.025\% (growing

finishing phase) microencapsulated complex of organic acids and essential oils; MOE2, basal + $0.2 \%$ (weanling phase) \& $0.05 \%$ (growing finishing phase) microencapsulated complex of organic acids and essential oils.

${ }^{\mathrm{b}}$ Standard error.

${ }^{\mathrm{c}} \mathrm{CON}$ vs MOE 1 vs MOE2.
} 
$\mathrm{OH}$ et al., Effects of organic acids and essential oils in weaning to finishing pigs

Table 9. The effect of microencapsulated complex of organic acids and essential oils supplementation on the meat quality in weanling to finishing pigs $^{\mathrm{a}}$

\begin{tabular}{|c|c|c|c|c|c|c|}
\hline Item & $\mathrm{CON}$ & MOE1 & MOE2 & $\mathrm{SE}^{\mathrm{b}}$ & Linear $^{\mathrm{c}}$ & Quadratic $^{c}$ \\
\hline \multicolumn{7}{|l|}{ Meat color } \\
\hline $\mathrm{L}^{*}$ & 55.65 & 56.03 & 54.31 & 1.00 & 0.210 & 0.254 \\
\hline$a^{*}$ & $16.47 a$ & $15.40 b$ & $15.55 b$ & 0.33 & 0.028 & 0.075 \\
\hline$b^{*}$ & 5.85 & 5.50 & 5.31 & 0.23 & 0.133 & 0.793 \\
\hline \multicolumn{7}{|l|}{ Sensory } \\
\hline \multicolumn{7}{|l|}{ evaluatio } \\
\hline \multicolumn{7}{|l|}{$\mathrm{n}$} \\
\hline Color & 2.92 & 3.00 & 2.86 & 0.16 & 0.770 & 0.539 \\
\hline Firmness & 1.04 & 1.08 & 1.04 & 0.14 & 1.000 & 0.535 \\
\hline Marbling & 1.04 & 1.12 & 20 & 0.08 & 0.195 & 1.000 \\
\hline \multicolumn{7}{|l|}{ Cooking } \\
\hline loss, $\%$ & 45.15 & 40.87 & 40.31 & 1.97 & 0.176 & 0.528 \\
\hline \multicolumn{7}{|l|}{ Drip loss, $\%$} \\
\hline d1 & 1.32 & 1.38 & 1.48 & 0.27 & 0.531 & 0.923 \\
\hline $\mathrm{d} 3$ & 4.46 & 3.92 & 3.75 & 0.39 & 0.122 & 0.618 \\
\hline d5 & 8.16 & 6.42 & 6.64 & 0.57 & 0.098 & 0.201 \\
\hline $\mathrm{d} 7$ & $13.35 a$ & $10.21 b$ & $10.77 b$ & 0.73 & 0.026 & 0.054 \\
\hline $\mathrm{pH}$ & 5.26 & 5.28 & 5.31 & 0.03 & 0.253 & 0.899 \\
\hline \multicolumn{7}{|l|}{ Lonmgissimus } \\
\hline muscle & 48.81 & 48.86 & 49.53 & 0.65 & 0.532 & 0.752 \\
\hline \multicolumn{7}{|l|}{ area, $\mathrm{cm}^{2}$} \\
\hline Water holding & & & & & & \\
\hline capacity, & 54.68 & 49.74 & 53 & 1.70 & 0.535 & 0.105 \\
\hline
\end{tabular}


$\%$

Note: Means in the same row with different superscripts differ $(\mathrm{P}<0.05)$.

${ }^{a}$ Abbreviation: CON, basal diet; MOE1, basal $+0.1 \%$ (weanling phase) \& $0.025 \%$ (growing finishing phase) microencapsulated complex of organic acids and essential oils; MOE2, basal + $0.2 \%$ (weanling phase) \& $0.05 \%$ (growing finishing phase) microencapsulated complex of organic acids and essential oils.

${ }^{\mathrm{b}}$ Standard error.

${ }^{\mathrm{c}} \mathrm{CON}$ vs MOE1 vs MOE2. 